\title{
The Promise of Pico: A New Definition of Orthodoxy
}

\author{
James C. O'Brien
}

Justice Brennan's opinion for the plurality in Board of Education v. Pico ${ }^{1}$ has confounded commentators. They interpret it as arguing that the right to receive information and ideas should extend to secondary school students. ${ }^{2}$ Interpreted this way, the opinion is an utter failure. It creates a right that forces public school officials to accede to student demands to retain any book..$^{3}$ It therefore undercuts community and professional control of schools. At the same time, the right applies only to the removal of books from libraries, leaving students unprotected in the classroom and in the process of selecting books. ${ }^{4}$

This Note argues that the Pico plurality opinion does not confer the right to receive ideas upon high school students. Instead, it invites contem-

1. 457 U.S. 853 (1982). Seven justices wrote opinions in Pico. Justices Stevens and Marshall joined Justice Brennan's opinion. Justice Blackmun joined all but one section. Justice White concurred in the result only. See infra note 35 (discussing opinions).

2. See, e.g., Pico, 457 U.S. at 887 (Burger, C.J., dissenting) (Justice Brennan's opinion requires that schools "be the courier" of all ideas); id. at 910 (Rehnquist, J., dissenting) (granting students a right to receive is "wholly unsupported by our past decisions and inconsistent with the necessarily selective process of elementary and secondary education"); Brown v. Board of Regents of Univ. of Nebraska, 640 F. Supp. 674, 678 (D. Neb. 1986); American Future Sys. v. Pennsylvania State Univ., 568 F. Supp. 666, 670 (M.D. Pa. 1983).

Academic commentators have also regarded Justice Brennan's opinion as extending the right to receive ideas to students. See, e.g., J. Bryson \& E. DETTY, CENSORSHIP OF Public School LIBRARY AND INSTRUCTIONAL MATERIAL 80-81 (1982); Bosmajian, The Judiciary's Use of Metaphors, Metonymies and Other Tropes to Give First Amendment Protection to Students and Teachers, 15 J. L. \& EDuc. 439, 459-60 (1986); Ingber, Socialization, Indoctrination, or the "Pall of Orthodoxy": Value Training in the Public Schools, 1987 U. ILL. L. F. 15, 53; Lee, The Supreme Court and the Right to Receive Expression, 1987 SuP. CT. REv. 303, 304, 323-26; Mitchell, Secularism in Public Education: The Constitutional Issues, 67 B.U. L. REv. 603, 717 (1987); van Geel, The Search for Constitutional Limits on Governmental Authority to Inculcate Youth, 62 TEX. L. REv. 197, 231 (1983); Yudof, Library Book Selection and the Public Schools: The Quest for the Archimedean Point, 59 IND. L.J. 527, 542 (1984); Note, State Indoctrination and the Protection of NonState Voices in the Schools: Justifying a Prohibition of School Library Censorship, 35 STAN. L. REv. 497, 507 (1983) [hereinafter Note, State Indoctrination].

3. See, e.g., Pico, 457 U.S. at 893 (Powell, J., dissenting) ("[A]ny junior high school student . . . may invite a judge to overrule an educational decision. . . ."); id. at 912 (Rehnquist, J., dissenting) (all authors could require that books be put into school libraries); see also Freeman, The Supreme Court and First Amendment Rights of Students in the Public School Classroom: A Proposed Model of Analysis, 12 Hastings Const. L.Q. 1, 43-50 (1984); Ingber, supra note 2, at 51 n.209 \& 54 n.221.

4. Justice Brennan limited his holding to the removal of books from school libraries. 457 U.S. at 862, 868. This limitation follows Pico's facts. The case involved the removal of eleven books from school libraries and one book from the twelfth-grade curriculum. See also Ingber, supra note 2, at 57-58. 
porary revision of the Court's long-standing principle that school officials may not "cast a pall of orthodoxy over the classroom"s and allows us to examine again the limits of schools' power to inculcate community values into students. This Note contends that public schools should be allowed to advocate community values, but that they must not be allowed to argue for those values unfairly. The Note suggests a definition of unfairness. It draws heavily from studies of the transmission of ideas within schools and throughout society. These studies establish that students already have access to ideas; orthodoxy arises in how schools present the ideas.

Section I surveys the doctrine that protects students against orthodoxy. It argues that, under that doctrine, orthodoxy exists when students are not trained to criticize systems of belief. It criticizes the Supreme Court's application of that principle. Section II develops a new definition of orthodoxy. It notes that students generally have access to ideas that are not endorsed by school officials. Schools influence how students evaluate those ideas and prevent students from developing the critical abilities emphasized in Supreme Court doctrine. First, schools define aspirational terms, such as "democracy," solely in terms of beliefs favored by school officials. Second, schools depict disfavored beliefs as utopian. Effective student protections against orthodoxy must forbid those argumentative techniques. Section III discusses how to implement an approach that recognizes this aspect of orthodoxy. Courts should declare that the First Amendment guards against orthodoxy in how ideas are discussed. Beyond this conversation-starting function, however, courts' role is limited. School officials, parents, and community groups must take the lead. They can rely on the educators who have developed educational programs compatible with the notion of orthodoxy developed here. ${ }^{B}$

5. Keyishian v. Board of Regents, 385 U.S. 589, 603 (1967). The Court first protected students from orthodoxy in Meyer v. Nebraska, 262 U.S. 390 (1923). See infra text accompanying notes 8-25 (describing development of orthodoxy test).

6. This Note might help in other areas of First Amendment law. For example, some scholars have argued that the First Amendment requires inclusion of dissenting voices in public debate. See J. BARron, Freedom of the Press For Whom? (1973); Fiss, Why the State?, 100 Harv. L. Rev. 781, 786 (1987). The authorities relied on in this Note contend that public debate may be orthodox even after all ideas are admitted. See infra notes 78-80. Current discussions of public debate, therefore, omit a condition necessary for robust public debate.

The Note might also help evaluate claims that public education contravenes the establishment clause or restricts the free exercise of religion. See, e.g., Smith v. Board of School Comm'rs of Mobile County, 827 F.2d 684 (11th Cir. 1987) (establishment clause); Mozert v. Hawkins County, 827 F.2d 1058 (6th Cir. 1987) (free exercise clause). Insofar as courts must determine whether the texts challenged in those cases present ideas in an orthodox manner, the framework of this Note will prove useful. Of course, the establishment and free exercise clauses implicate concerns and precedents beyond the scope of this Note. This Note therefore will not discuss claims brought under those clauses. 


\section{The Doctrinal Basis For Expanding the Ban on ORTHODOXY}

This Section presents an internal critique of the Supreme Court's orthodoxy doctrine. That doctrine is organized around two often conflicting imperatives, public schools' interest in inculcating community values and their duty to prepare students for citizenship. ${ }^{7}$ The latter duty is defined by the Court's First Amendment jurisprudence. The Section argues that each time the Court's First Amendment doctrine announces a new prerequisite for self-government, that prerequisite must be incorporated into public schools.

The Section also criticizes the Court's application of the First Amendment in public schools. The Court often limits schools' power to advocate community values. This approach overlooks the importance of instilling those values in students. It also protects students' First Amendment rights inadequately. The erosion of schools' ability to argue for community values causes subsequent courts to return too much power to school officials and thus to impair students' rights. This see-saw approach to schools' constitutional duties benefits no one.

\section{A. Setting The Stage For Pico: From Meyer to Tinker}

The connection between student protections against orthodoxy and First Amendment doctrine is evident in the origins of them both. Students received no protection against orthodoxy until the $1920^{\prime} \mathrm{s}^{8} \mathrm{Just}$ after World War I, however, the Court began to acknowledge that individual autonomy was sharply implicated by the ability to express ideas. ${ }^{\circ}$ The Court

7. Public schools officials may "establish and apply their curriculum in such a way as to transmit community values." Pico, 457 U.S. at 864 (opinion of Brennan, J.) (quoting Brief for School Board at 10). See Hazelwood School Dist. v. Kuhlmeier, 108 S. Ct. 562, 570-71 (1988); Ambach v. Norwick, 441 U.S. 68, 77 (1979). Public schools must also foster "the individual freedom of mind" essential to effective self-government. West Va. State Bd. of Educ. v. Barnette, 319 U.S. 624, 637 (1943); see also Note, State Indoctrination, supra note 2, at 532 (Supreme Court requires that public schools prepare students for personal and societal self-government). See generally Levin, Educating Youth for Citizenship: The Conflict Between Authority and Individual Rights in the Public School, 95 YALE L. J. 1647 (1986) (review of Supreme Court decisions); The Supreme Court, 1981 Term, 96 HaRv. L. REv. 1, 151-60 (1982) (conflict between freedom and inculcation irreconcilable).

8. See Tyack \& Benavot, Courts and Public Schools: Educational Litigation in Historical Perspective, 19 LAW \& Soc'y REv. 339 (1985) (19th century litigation over schools concerned creation of school districts and their funding, rarely touched on content of curriculum). Most early schools were associated with churches and other groups that openly avowed their intentions to inculcate orthodoxy in students. This fact lends significance to the absence of judicial protection. See Note, Education and the Court: The Supreme Court's Educational Ideology, 40 VAND. L. REv. 939, 944 (1987) (describing history of schools).

9. The degree to which individuals could be said to have rights to free speech, and the extent of those rights they had, became a focus of disagreement in the Supreme Court at about the time the Court first recognized students' right to be free of state-imposed orthodoxy. See Schenck v. United States, 249 U.S. 47 (1918) (conviction of pamphleteers upheld); Abrams v. United States, 250 U.S. 616 (1919) (same); id. at 658 (Holmes, J., dissenting) (arguing that pamphleteers lacked intention to implement opinions and should therefore have been said to have been exercising their rights to free speech). 
first protected students against orthodoxy in the early 1920 's. ${ }^{10}$ The pendulum swung back toward school officials once the Court became concerned with national harmony just before the start of World War II, however. ${ }^{11}$

This early protection was very limited. The Court invalidated public school policies only when they threatened to create uniformity of belief or opinion among students. ${ }^{12}$ The proscription against orthodoxy, then, offered students the limited right to be free of efforts to produce conformity of belief or expression. ${ }^{13}$ The provenance of the early orthodoxy doctrine partly explained its narrow scope. In Meyer and Pierce, student protections against orthodoxy rested in the Fourteenth Amendment. ${ }^{14}$ This amendment protected only those "fundamental rights" of individuals covered by the Court's substantive due process doctrines. ${ }^{18}$ Curricular decisions apparently did not implicate those fundamental rights. ${ }^{16}$ Not surprisingly, most plaintiffs relying on Meyer and Pierce lost. ${ }^{17}$

The orthodoxy doctrine's interaction with the Court's First Amendment jurisprudence soon changed that. In 1925, the Court held that the First Amendment applied to the States. ${ }^{18}$ By the time Barnette was decided in

10. In Meyer v. Nebraska, 262 U.S. 390 (1923), the Supreme Court struck down state laws that forbade the teaching of German to young students. Soon after Meyer, Pierce v. Society of Sisters, 268 U.S. 510 (1925), invalidated state laws which required all students to attend public schools. In West Va. State Bd. of Educ. v. Barnette, 319 U.S. 624 (1943), the Court ruled unconstitutional West Virginia's requirement that students pledge allegiance to the United States flag. See Ross, A Judicial Janus: Meyer v. Nebraska in Historical Perspective, 57 U. GIN. L. REv. 125, 185-203 (1988) (arguing that Meyer increased Court's willingness to protect individual liberties).

11. See Minersville School Dist. v. Gobitis, 310 U.S. 586 (1940), overruled, West Va. State Bd. of Educ. v. Barnette, 319 U.S. 624 (1943).

12. In Meyer, the Court held that statutes proscribing instruction in German were unconstitutional efforts to "foster a homogeneous people." 262 U.S. at 402 . The Court described its holding in Pierce as a limitation on states' power to "standardize" their citizens. Id. at 535. Finally, Justice Jackson's opinion in Barnette rested on the premise that the First Amendment forbade school authorities from attempting "compulsory unification of opinion" by requiring students to express beliefs supported by school authorities. 319 U.S. at $641-42$.

13. Meyer, Pierce, and Barnette involved statutes that dictated to all children, stipulating (respectively) what they must or must not study, where they would study, and what beliefs they would express. The Court implied that less universal inculcation would be constitutional. For example, Meyer promised only that the United States would not become Sparta or Plato's Republic. 262 U.S. at 401-02. Also, the least accommodation of dissent satisfied the Court. West Virginia's flag salute regulations were initially challenged by the P.T.A., the Girl and Boy Scouts, the Red Cross, and the Federation Womens' Clubs, in addition to the Jehovah's Witnesses. 319 U.S. at 627-28. Only the group that was forced to "conform," id. at 629 , came before the Court. Justice Jackson noted in passing that "concessions" were made to these groups but not to the Jehovah's Witnesses. Id. at 628 . He did not describe these concessions. This omission suggested that by making any concessions the board established that it did not want to impose orthodoxy on those groups. But see Note, State Indoctrination, supra note 2 (arguing that Meyer, Pierce, and Barnette created expansive student rights).

14. Meyer derives the protection from students' substantive due process rights. See Meyer, 262 U.S. at 401; Pierce, 268 U.S. at 534-35.

15. Meyer, 262 U.S. at 401.

16. Meyer did not curtail states' power to "prescribe a curriculum." Id. at 402.

17. See Note, State Indoctrination, supra note 2, at 527 n.106 (surveying cases brought under Meyer and Pierce).

18. See Gitlow v. New York, 268 U.S. 652 (1925). Gitlow was announced one week after Pierce. 
1943, the Court had recast the ban on orthodoxy as a First Amendment right. ${ }^{18}$ The First Amendment brought new considerations to bear on judicial review of school officials' decisions. The primary one was the requirement that schools prepare students for self-government. Justice Jackson, writing for the Court, stressed that public schools were "educating the youth for citizenship." 20 The students would practice this "citizenship" in a country that prized diversity and dissent. ${ }^{21}$ The very structure of the government that these citizens would control preserved diversity. ${ }^{22}$ Hence, public schools had to embody intellectual openness, lest they "teach youth to discount important principles of our government as mere platitudes." ${ }^{23}$ The Barnette Court deduced the proscription of orthodoxy from the First Amendment's role in the structure of American government. ${ }^{24}$ After Barnette, then, the orthodoxy doctrine no longer supported limiting student protections to their fundamental rights.

Over the next twenty-five years, the doctrinal basis for limiting students' protection against orthodoxy to conformity eroded further. The Court strengthened the free speech rights of public school teachers. ${ }^{25}$ Over the same period, the Court's First Amendment decisions placed increasing emphasis on the right to receive information and ideas. ${ }^{26}$ These changes in doctrine broadened the idea of self-government to which schools were responsible. It now included a measure of individual freedom of inquiry and

19. See, e.g., Minersville School Dist. v. Gobitis, 310 U.S. 586 (1940), overruled, West Va. State Bd. of Educ. v. Barnette, 319 U.S. 624, 642 (1943). Ross argues that the shift in doctrinal basis merely acknowledged that Meyer and Pierce prepared the Court to extend the First Amendment to the states. See Ross, supra note 10.

20. 319 U.S. at 637.

21. According to Justice Jackson, America thrives on "the right to differ as to things that touch the heart of the existing order." Id. at 642 .

22. Id. at 638 ("The very purpose of a Bill of Rights was to withdraw certain subjects from the vicissitudes of political controversy ....").

23. Id. at 637.

24. Barnette sits in a line of cases in which the Supreme Court tacitly endorsed the deductionfrom-structure approach. See Grosjean v. American Press Co., 297 U.S. 233, 245-50 (1936); United States v. Associated Press, 52 F. Supp. 362, 372 (S.D.N.Y. 1943), affd, 326 U.S. 1 (1944); Pennenkamp v. Florida, 328 U.S. 331, 354-55 (1946) (Frankfurter, J., concurring); Terminello v. Chicago, 337 U.S. 1 (1949). The structural approach grew into a full-fledged theory in the work of Alexander Meiklejohn at about that time. Meiklejohn argued that free speech furthers selfgovernment by citizens. Governmental action must be evaluated by whether it helps or hinders speech in playing that role. See A. MeIkLejohn, Free Speech and Irs Relation to Self-Government (1948); see also Note, State Indoctrination, supra note 2, at 518-21 (proposing that self-government rationale control judicial review of school officials' decisions).

25. See, e.g., Wieman v. Updegraff, 344 U.S. 183, 196 (1952) (Frankfurter, J., concurring). These developments gained momentum in the late 1960's. See, e.g., Pickering v. Board of Educ., 391 U.S. 563 (1968) (rights of secondary school teacher); Keyishian v. Board of Regents, 385 U.S. 589 (1967) (college instructor). See generally Developments in the Law-Academic Freedom, 81 HaRv. L. REv. 1045 (1968). A respected lower court opinion typified developments at that time. See James v. Board of Educ., 461 F.2d 566 (2d Cir.), cert. denied, 409 U.S. 1042 (1972) (secondary school teacher).

26. The Court recognized the right to receive ideas the same sitting it decided Barmette. See Martin v. Struthers, 319 U.S. 141 (1943). It further developed the right in Lamont v. Postmaster General, 381 U.S. 301 (1965). A majority of the Court first embraced the right in Stanley v. Georgia, 394 U.S. 557 (1969). 
expression, of freedom from centralized control. This freedom could not be unlimited, however, for public schools still had to inculcate community values.

Hence, Tinker v. Des Moines Independent Community School District $t^{27}$ only partly reflected the developments in the orthodoxy doctrine. The Court invalidated the suspension of students who expressed political views at odds with views favored by school authorities. The Court described the suspensions as impermissible attempts to make students into "closed-circuit recipients of only that which the State chooses to communicate."28

The Court's assertion was implausible. The school limited only one form of expression. It did not deny students access to ideas outside the school. There was no realistic danger of a "closed-circuit" that would produce conformity of belief in students. In contrast, the programs invalidated in the earlier cases were much more far-reaching. Meyer, Pierce, and Barnette struck down state-wide laws dictating what students would study, where they would study, and what political beliefs thay would express. ${ }^{29}$ In Tinker, then, the Court in fact diverged from its traditional definition of orthodoxy.

The actual violation in Tinker became apparent only when seen through the lens of the structural insight that motivated Barnette. The opinion quoted Keyishian v. Board of Regents, emphasizing that individual freedom to inquire insured "wide exposure to that robust exchange of ideas" upon which the "Nation's future depends." punished some students for inquiring and no doubt inhibited the inquiry of others. They therefore impaired the students' training for selfgovernment. Nevertheless, the Court's reference to a "closed-circuit" hewed to the definition of orthodoxy as conformity.

The Tinker Court's reluctance to abandon the conformity definition stemmed in part from concern for public schools' inculcative function. Unless schools could praise some ideas and condemn others, they could not advocate community values. A reasonable accomodation of both inculcation and preparation for self-government was to cast the school as having gone too far, without saying that what the school did was wrong in itself. This was what the Court did by resorting to the flimsy fiction that the suspensions posed a risk of conformity. ${ }^{3 \mathrm{I}}$

27. 393 U.S. 503 (1969).

28. Id. at 511. The Court stressed that student protests against the Vietnam War had been "singled out for prohibition" by the school administration. Id. at 510-11. The administration allowed students to express viewpoints on other controversial issues. Id. The Court held that students had a right to express opinions, so long as their expression "did not materially disrupt" normal educational activities. Id. at 509 .

29. Meyer v. Nebraska, 262 U.S. 390 (1923); Pierce v. Society of Sisters, 290 U.S. 510 (1925);

West Va. State Bd. of Educ. v. Barnette, 319 U.S. 624 (1943). See supra notes 10, 13.

30. See 393 U.S. at 512 (quoting 385 U.S. 589, 603 (1967)).

31. See Note, The Supreme Court, 1968 Term-Leading Cases, 83 Harv. L. Rev. 154, 160 
Buried in the opinion was a major innovation, however. Justice Fortas noted that school officials would violate students' First Amendment rights by creating a "safe-haven for crackpots" outside the usual flow of ideas. ${ }^{32}$ This standard is novel within the orthodoxy tradition. By allowing the ideas into the school, even into a "safe-haven," school officials would satisfy the orthodoxy test. Because the school would also not use its disciplinary power to punish the expression of disfavored ideas, school officials would escape Tinker's test. Instead, the "safe-haven" would signal that ideas placed there ought not be taken seriously. The school would have unfairly affected how students evaluate ideas after the ideas were admitted to the school. This aspect of the Tinker opinion heralded for the first time judicial willingness to examine how public schools affected the evaluation of ideas, rather than merely how schools controlled student access to ideas.

The Court did not develop this insight. On the surface of the opinions in the Meyer-Tinker line of cases, then, the Court's concern with orthodoxy was implicated only when the justices were persuaded that school officials had tried to achieve uniformity of opinion. Bubbling under the surface, however, was a much broader right. The justices had established that self-government presupposed individual freedom to inquire, to receive ideas, and, perhaps, to be free of undue influence in evaluating those ideas.

\section{B. The Promise of Pico}

The definition of orthodoxy as conformity remained unchallenged until Pico, in 1982..$^{33}$ Pico arose when the Island Trees School Board removed eleven books from school libraries and one book from its curriculum. Students sued. ${ }^{34}$ The Supreme Court held that the students had stated a claim upon which relief could be granted. It splintered, writing seven opinions. ${ }^{85}$

(1969).

32. 393 U.S. at 513.

33. 457 U.S. 853 (1982).

34. The district court granted summary judgment for the school board on the ground that the student plaintiffs had not stated a claim on which relief could be granted. 474 F. Supp. 387 (E.D.N.Y. 1979). A divided panel of the Second Circuit reversed and remanded the case for trial. 638 F.2d 404 (2d Cir. 1980). Before the case went to trial, the Supreme Court granted certiorari. 454 U.S. 891 (1981). After the Supreme Court's decision, 457 U.S. 853 (1982), the school board returned the books. The case never went to trial.

35. Justices Stevens, Marshall, Brennan, Blackmun, and White affirmed the Second Circuit. Justices Rehnquist, Powell, O'Connor, and Chief Justice Burger dissented. There were three opinions from the justices in the majority, four by the dissenters. Justices Stevens and Marshall joined a plurality opinion written by Justice Brennan. This opinion held that public school officials could not remove books "simply because they dislike the ideas in them." 457 U.S. at 872 . Justice Blackmun said that school boards could remove books for "politically neutral" reasons. Id. at 880 (Blackmun, J., concurring). He joined the plurality for its standard. Justice White argued that further findings of fact were necessary. He contended that it was inappropriate to address the constitutional issue. Id. at 883 (White, J., concurring). The dissenting justices favored the traditional interpretation of the orthodoxy test. See, e.g., id. at 889 (Burger, C.J., dissenting) (all dissenting justices joining). 
Justice Brennan's opinion for the plurality makes a subtle but significant break from the Meyer-Tinker tradition. The opinion concluded that the evidence did not foreclose the possibility that the School Board had attempted "to impose upon the students. . .a political orthodoxy to which [the members of the Board] and their constituents adhered." ${ }^{38}$ A majority of the Court supported this conclusion. ${ }^{37}$ The opinion drew on the MeyerTinker line of cases. ${ }^{38}$ Yet it applied those cases when there was no risk of conformity. Students had access to ideas outside the library; they might have been taught them in the classroom. Unlike the opinion in Tinker, the Pico plurality did not even assert that the school officials sought conformity. The orthodoxy found in the Pico plurality opinion, then, lacked the central defining feature of the orthodoxies struck down in the cases on which the opinion relied. This shift was correct. After Tinker, the Court's First Amendment cases had changed the prerequisites for self-government. This required the Court to alter the duty of public schools to prepare students for self-government. Justice Brennan cast a spotlight on this evolution. He placed the right to receive ideas and the academic freedom cases, important in Tinker, into the structural model prominent in Barnette. The opinion's premise was that public schools must prepare students for self-government. ${ }^{39}$ This recalled Barnette's emphasis on preparing students for "citizenship."40 The opinion then discussed what the Court required schools to do in order to prepare students for citizenship. One requirement emerged from the right to receive ideas doctrine, which had grown in significance since Tinker. ${ }^{41}$ During this time, courts strug-

36. Id. at 875 .

37. Justices Stevens, Marshall, and Blackmun all joined this part of the opinion. Justice White's agreement must be inferred from his concurrence. The plaintiffs argued that the attempted imposition of orthodoxy was a claim upon which relief could be granted. The case presented the Court with only the limited question of whether it was. Justice White's vote to remand for trial implied that he accepted the viability of the claim.

38. The opinion illustrated students' First Amendment rights by describing Barnette and Tinker. 457 U.S. at 865-66. In articulating the First Amendment's restrictions on removal of books from school libraries, Justice Brennan wrote that he relied on "the guidance of several precedents," most notably Barmette's conclusion that "no official, high or petty, can prescribe what shall be orthodox in politics, nationalism, religion, or other matters of opinion," id. at 869-70 (quoting Barnette, 319 U.S. at 642), and Keyishian's principle that "the First Amendment . . . does not tolerate laws that cast a pall of orthodoxy over the classroom," id. at 870 (citing Keyishian, 385 U.S. at 603).

39. 457 U.S. at 866 . The structural perspective gained importance after Barnette was decided in 1943. See Roth v. United States, 354 U.S. 476, 484 (1957); New York Times Co. v. Sullivan, 376 U.S. 254, 269-70 (1964); Garrison v. Louisiana, 379 U.S. 64, 74-75 (1964). Justice Brennan authored these opinions, as well as an influential concurrence in Lamont v. Postmaster General, 381 U.S. 301 (1965) (Brennan, J., concurring). See Brennan, The Supreme Court and the Meiklejohn Interpretation of the First Amendment, 79 HARv. L. Rev. 1 (1965); Kalven, The New York Times Case: A Note on "The Central Meaning of the First Amendment", 1964 SuP. CT. REv. 191 (1965).

40. See supra text accompanying notes 20-23.

41. See Red Lion Broadcasting Co. v. FCC, 395 U.S. 367, 390 (1969) (the "right of viewers and listeners . . . is paramount"); Kleindeist v. Mandel, 408 U.S. 753, 763 (1972) (right to receive information and ideas "vital" in schools and universities); Procunier v. Martinez, 416 U.S. 396 (1974) (right to receive uncensored letters from prisoners); Virginia State Bd. of Pharmacy v. Virginia Citizens Consumer Council, 425 U.S. 748, 756-57 (1978) (right to receive commercial information). 
gled with its effect on students' protection from orthodoxy. ${ }^{42}$ Justice Brennan correctly declared that this doctrine established that access to ideas nurtured the analytical abilities crucial to citizenship. ${ }^{43}$ Another precondition for self-government arose from the academic freedom cases. This doctrine had applied primarily to post-secondary school teachers. ${ }^{44}$ By the 1980's, courts had extended that freedom to secondary and primary school teachers. ${ }^{45}$ Justice Brennan declared that individuals' ability to seek out ideas on their own enhanced the evaluation of ideas essential to selfgovernment. ${ }^{46}$ The two doctrines together defined what was necessary to prepare students for participation as citizens: a range of ideas and the ability to select from them voluntarily. This required discarding the traditional definition of orthodoxy as conformity.

Commentators interpreted this opinion as granting students a right to receive ideas. ${ }^{47}$ The right to receive played a subordinate role throughout the opinion. The opinion defined students' First Amendment freedoms by describing the facts of Tinker and Barnette. ${ }^{48}$ Only then did it introduce the right to receive ideas. ${ }^{49}$ The holding of the opinion focused on students' protection against orthodoxy. ${ }^{50}$ The right to receive ideas might allow students to demand access to any and every idea. The orthodoxy test grants them a right only to ideas that dispel orthodoxy. The definition of orthodoxy will determine what information they will receive.

Justice Brennan's opinion in Pico wove together the doctrinal threads that had influenced the orthodoxy doctrine. In doing so, it eviscerated the constricted definition of orthodoxy as conformity and laid out the minimal requirements any new definition would have to meet. That definition must prepare students for self-government by enabling individual inquiry and by allowing students to evaluate ideas without interference from

42. Compare Right to Read Defense Comm. of Chelsea v. School Comm., 454 F. Supp. 703, 714 (D. Mass. 1978) (students must "be exposed to controversial thoughts and ideas") and Minarcini v. Strongsville City School Dist., 541 F.2d 577 (6th Cir. 1976) (same) with Zykan v. Warsaw Community School Corp., 631 F.2d 1300, 1306 (7th Cir. 1980) (requiring plaintiffs to demonstrate that school authorities attempted "rigid and exclusive indoctrination") and Island Trees Union Free School Dist. v. Pico, 638 F.2d 404, 417 (2d Cir. 1980) (Sifton, J.) (requiring showing that school board tried to impose "orthodoxy for all purposes in the particular community") and Presidents Council v. City School Bd., 457 F.2d 289 (2d Cir.), cert. denied, 409 U.S. 998 (1972) (school boards may shape educational policy to conform to values of members). An interesting compromise was attempted in Pratt v. Independent School Dist. No. 831, 670 F.2d 771, 775-79 (8th Cir. 1982) (allowing removal of books for ideological reasons but also requiring nonideological justification).

43. 457 U.S. at 868.

44. See, e.g., Keyishian v. Board of Regents, 385 U.S. 589 (1967) (college instructor).

45. See, e.g., Mt. Healthy City School Dist. Bd. of Educ. v. Doyle, 429 U.S. 274 (1977) (reviewing cases); James v. Board of Educ., 461 F.2d 566 (2d Cir. 1972) (secondary school teacher).

46. 457 U.S. at 869 (quoting Right to Read Defense Comm. v. School Comm., 454 F. Supp. 703, 715 (D. Mass. 1978)).

47. See supra note 2.

48. 457 U.S. at $865-66$.

49. Id. at 866-68.

50. Id. at 875 . 
school officials. Only then can students learn to criticize, a skill essential to self-government.

\section{G. The Problem of Pico: Defining Orthodoxy}

Unfortunately, Justice Brennan's opinion did not fulfill its promise. Although the opinion held that the evidence did not foreclose the possibility that the Island Trees School Board attempted to impose orthodoxy, ${ }^{{ }_{1} 1}$ it did not define the "orthodoxy" it found in the Island Tree Schools. Instead, it declared that school officials could not remove books "simply because they dislike the ideas in them." bers belonging to the Democratic Party, "motivated by party affiliation," could not remove all books favoring the Republican Party. ${ }^{53}$ The opinion required that school officials follow regular procedures when deciding whether to remove books from libraries. ${ }^{54}$ This requirement increased the likelihood that legitimate reasons would predominate in deliberations. ${ }^{5 s}$ The sin of the Island Trees School Board was that it did not follow its own procedures for evaluating books. ${ }^{56}$

The plurality opinion could not protect students adequately. Schools might design procedures that did not curtail school officials' discretion. ${ }^{57}$ The opinion also did not hold that mere violation of designated procedures violated the First Amendment. ${ }^{58}$ Plaintiffs able to prove procedural irregularities might therefore be required to establish the existence of illegitimate motivations in order to state a claim under Pico. The opinion discussed only readily identifiable prejudices, such as membership in a political party. ${ }^{59}$ It did not discuss whether less overt biases would violate the First Amendment. Even a readily identifiable bias would not invalidate school officials' decisions if there were a legitimate basis for the removal of the book. ${ }^{60}$ It did not address how courts could identify motivations that were not obvious. Officials might mask prejudices behind legitimate administrative or educational rationales. ${ }^{\text {Bd }}$ Members might re-

51. Id.

52. Id. at 872 .

53. Id. at 870-71. Also, an "all-white school board, motivated by racial animus" could not "remove all books authored by blacks or advocating racial equality and integration." Id. at 871 .

54. Id. at $874-75$.

55. See Comment, Board of Education, Island Trees Union Free School District No. 26 v. Pico, 12 Hofstra L. Rev. 561, 578-79 (1984).

56. 457 U.S. at 858,874 . The School Board appointed a committee to review the books. The Board agreed to adopt the committee's recommendation. In fact, however, it did not.

57. For example, procedures might allow removal solely upon the complaint of a school board member or citizen. They might delay discussion in order to quiet controversy. Procedures might also not prevent clandestine removal. See Ingber, supra note 2, at 62.

58. 457 U.S. at $874-75$.

59. Id. at $870-71$.

60. Id. at 871,875 .

61. See van Geel, supra note 2, at 208 n.41; Case Comment, Education or Indoctrination-Removal of Books from Public School Libraries, 68 MiNN. L. REv. 213, 246 n.188 (1984). 
fuse to articulate any rationale, leaving courts to rely on the crafted opinions of a few school board members. ${ }^{62}$ Courts might refuse to investigate the reasons for a school board's decision..$^{6 s}$ Finally, even if the plaintiffs could prove the influence of illegitimate motivations, the opinion did not say who carried the burden of establishing that those motivations were important in the school board's decision. ${ }^{64}$

The greatest problem with the opinion was that it ran off the track of its own argument. The insight driving the opinion was that the definition of orthodoxy as conformity had become obsolete under First Amendment doctrine. The opinion should have announced a definition of orthodoxy to replace the discarded conformity interpretation. This definition would have provided a substantive baseline for the content of school curricula and libraries. Under the procedural test it announced, however, orthodoxy imposed through regular channels would not violate the First Amendment.

The limitations of Justice Brennan's opinion are understandable. It took a first step into uncharted territory. It decided a motion for summary judgment and thus was announced without the record that would have helped in articulating a more detailed standard. ${ }^{65}$ His adherence to precedent also limited the reach of his opinion. ${ }^{66}$ At the same time, the con-

62. Several members of the Island Trees School Board refused to articulate their reasons. See S. abrams, Compeling Belief: The Culture of American Schooling (1983).

63. In Pico a conservative parents' organization spearheaded the drive to remove the books. The plurality inferred illegitimate motivations from that fact. 457 U.S. at 874 . Compare Epperson v. Arkansas, 393 U.S. 97 (1967) (finding unconstitutional legislative intent to establish religion by examining motives of those who lobbied legislature) and Loewen v. Turnipseed, 488 F. Supp. 1138, 1147 (N.D. Miss. 1980) (rejecting proffered rationales for textbook selection) with Solmitz v. Maine Admin. School Dist., 495 A.2d 812, 818 (Me. 1985) (court should not impute to school board "invidious" motivation of parents who influenced decision to cancel play).

64. Justice Brennan recommended that the Mt. Healthy rule fill this gap. 457 U.S. at 871 n. 22 (citing Mt. Healthy Gity School Dist. Bd. of Educ. v. Doyle, 429 U.S. 274 (1977)). Plaintiffs must establish the influence of illegitimate motivations in a decisionmaking process. Upon this showing, the burden lies with the defendants to establish that their decision would have been the same if the illegitimate motivations had not influenced the decision. See Mt. Healthy, 429 U.S. at 287.

The $M t$. Healthy rule would help plaintiffs only minimally. Courts have traditionally deferred to school officials' judgments about the educational suitability of materials. They might therefore be too willing to accept school officials' assertions that educational concerns alone justified their decision. See supra notes 7 \& 61 .

65. For this reason, Justice White's refusal to decide the constitutional issue was insightful. 457 U.S. at 883 (White, J., concurring).

66. The limits of the pluralty opinion stemmed directly from Justice Brennan's use of precedents. He explicitly limited his opinion to the removal of books from school libraries. Id. at 868. Many school cases involved libraries. See, e.g., Brown v. Louisiana, 383 U.S. 131 (1966) (protecting protest in libraries); Pratt v. Independent School Dist. No. 831, 670 F.2d 771 (8th Cir. 1982); Bicknell v. Vergennes Union High School, 638 F.2d 438 (2d Cir. 1980) (no majority opinion); Minarcini v. Strongsville School Dist., 541 F.2d 577 (Gth Cir. 1976); Salvail v. Nashua Bd. of Educ., 469 F. Supp. 1269 (D.N.H. 1979); Right to Read Defense Comm. v. School Comm., 454 F. Supp. 703 (D.Mass. 1978). But see 457 U.S. at 914-15 (Rehnquist, J., dissenting) (precedents do not support distinctive role of libraries). Other precedents developed procedural solutions. See Loewen v. Turnipseed, 488 F. Supp. 1138 (N.D. Miss. 1980); Gottlieb, In the Name of Patriotism: The Constitutionality of "Bending" History in Public Secondary Schools, 62 N.Y.U. L. REv. 497, 520-21 (1987) (describing procedural solutions in academic freedom cases). 
straining precedents he relied upon linked Pico to a tradition that evolved within the First Amendment. The very choice that helped limit the opinion thus also gave it the materials on which it could grow. ${ }^{67}$

\section{Beyond Pico}

The opinion has lain fallow, however. Disputes over public schooling have focused on the substantive information students should or should not hear. ${ }^{68}$ Increasing numbers of topics and groups squeeze into an already crowded school day, leaving students little time to absorb the information thrust upon them. ${ }^{69}$ These disputes often bring with them the requirement that teaching be value neutral, that public schools are forbidden to argue for community values for fear of suppressing other viewpoints. ${ }^{70}$ Value neutrality will likely lead to another swing of the pendulum, as courts will react to fears that communities are disintegrating. Suggestions by academics add to this problem, producing only amorphous guidelines outlining more of what schools may or may not teach; these suggestions are of little

67. This attachment to precedent makes Justice Brennan's opinion more fertile than Justice Blackmun's concurring opinion. Justice Blackmun advised the Court to hold "that school officials may not remove books for the purpose of restricting access to the political ideas or social perspectives discussed in them, when that action is motivated simply by the officials' disapproval of the ideas involved." 457 U.S. at 879-80 (Blackmun, J., concurring). Justice Brennan linked motivation to objective prejudice. See supra text accompanying notes 53, 59-63. Justice Blackmun's approach, however, is wholly subjective. It is therefore more susceptible to the difficulties outlined above. See Note, Judicial Clairvoyance and the First Amendment: The Role of Motivation in Judicial Review of Book Banning in the Public Schools, 1983 U. ILL. L.F. 731, 737-39 (contrasting motivation test suggested by Justice Brennan to that advocated by Justice Blackmun).

Some commentators have preferred Justice Blackmun's opinion to Justice Brennan's. See, e.g., Ingber, supra note 2, at 60-61; Lee, supra note 2, at 326; Note, State Indoctrination, supra note 2, at 533. Justice Blackmun certainly stated the underlying issue in the case more straightforwardly than did Justice Brennan: When does inculcation of values become imposition of orthodoxy? 457 U.S. at 879 (Blackmun, J., concurring). He demurred from Justice Brennan's analysis of the influence the right to receive ideas had on the protection of students against orthodoxy. He therefore had no doctrinal basis for applying the Meyer-Tinker cases when there was no conformity.

Justice Blackmun's deviation from precedent has implications other than accusations of judicial activism. By tying the orthodoxy doctrine to other First Amendment doctrines, Justice Brennan identified a pattern of development for the new right. Justice Blackmun severed the link between the orthodoxy doctrine and other First Amendment rights. Ironically, then, by freeing his own opinion from the constraints of precedent, Justice Blackmun deprived the right he sought to develop of the tradition that could nurture its growth.

68. See Sewall, American History Textbooks: An Assessment of Quality 68-69 (1987) (Report for Educational Excellence Network) (available from Teachers College, Columbia University) (groups "slighted" in history books pressure for inclusion in history texts); Tyack \& Benavot, supra note 8, at 375 (describing increasing use of litigation by minority groups); Glenn, Textbook Controversies-A "Disaster" for Public Schools?, Phi Delta Kappan 451, 451 (1987) (general), 454 (gender). Pressures to include even more will soon increase. See, e.g., "Pressures" for Creationism To Be Revisited, Educ. Week, Feb. 10, 1988, at 28, col. 1; Glenn, supra, at 451 (predicting "flood" of litigation over content of public schooling). Scholars reflect this focus on content. See, e.g., Gottlieb, supra note 66 (advocating "Fairness Doctrine" in public schools).

69. See Sewall, supra note 68.

70. See Sewall, supra note 68 (value neutrality undermines educational effectiveness of textbooks). 
use to school officials and courts. ${ }^{71}$ Finally, giving students access to ideas does not alone protect them against orthodoxy. ${ }^{\mathbf{2 2}}$

More troubling, the Supreme Court itself has shown signs of retreating to its traditional definition of orthodoxy as conformity. This exemplifies the see-saw tendencies that have been with the orthodoxy doctrine from its origins. In Hazelwood School District $v$. Kuhlmeier, the Court allowed a high school principal to remove several pages from a student newspaper. ${ }^{73}$ Kuhlmeier will influence the orthodoxy doctrine. ${ }^{74}$ The extent and nature of this influence is not yet settled, however. Courts and commentators should work to limit it. The opinion ignores the relevant precedents, the orthodoxy cases. ${ }^{75}$ It creates an unprecedented category of "state-

71. Gottlieb advocated a fairness doctrine for public schools: When important issues over which there was controversy in the community were discussed in schools, schools had to present both sides. Gottlieb, supra note 66, at 561-73. Important issues were those "important to constitutional values," $i d$. at 570 , especially those about participation in government. Id. at $572-73$. He did not identify those issues. Gottlieb's standard would be satisfied if curricula were made to include the views of dissenting groups. Id. at 572-3. He did not address how those ideas should be discussed. The manner of presentation is the focus of this Note. See also Gordon, Freedom of Expression and Values Inculcation in Public School Curriculum, 13 J.L. \& EDuc. 523 (1984) (arguing that states can inculcate only those values found in state constitutions; admitting that this standard does not specify how courts can determine whether only constitutional values are included in curriculum); Note, State Indoctrination, supra note 2, at 520 (requirement that schools provide information that tends to prepare students for self-government would "rarely provide a judge with clear-cut practical guidance in actual cases"); Orleans, What Johnny Can't Read: 'First Amendment Rights' in the Classroom, 10 J.L. \& EDuc. 1, 14 (1981) (use of Thirteenth and Fourteenth Amendments instead of First Amendment to prevent inculcation of racism is difficult to apply because "consensus as to what in text is racist" hard to achieve). Kamenshine proposed a prohibtion on "political establishments." Kamenshine, The First Amendment's Implied Political Establishment Clause, 67 Calrf. L. REv. 1104 (1979). He did not discuss how courts would recognize when school officials are attempting "political establishment." See id. at 1132-38 (discussing implementation of standard in schools).

72. See infra text accompanying notes 78-92.

73. $108 \mathrm{~S}$. Ct. 562 (1988). The principal feared that the articles invaded the privacy of several students and parents. The Court held that public school officials could restrict state-sponsored student speech so long as the restriction was "reasonably related to legitimate pedagogical concerns." Id. at 571.

74. Changes in First Amendment doctrine have always influenced student protections against orthodoxy. See supra text accompanying notes $9,18-26$. The influence may be particularly direct here. The Court required that restrictions on student expression be merely "reasonable." $108 \mathrm{~S}$. Ct. at 571. This might permit punishment or prohibition of student speech that "frustrates the school's legitimate pedagogical purposes merely by expressing a message that conflicts with the school's." Id. at 574 (Brennan, J., dissenting); see also id. ("A student who responds to a political science teacher's question with the retort, 'Socialism is good,' subverts the school's inculcation of the message that capitalism is better.").

Kuhlmeier has already eroded students' First Amendment protections. See Virgil v. School Bd. of Columbia County, 677 F. Supp. 1547 (M.D. Fla. 1988) (upholding removal of text containing Lysistrata and Chaucer's The Miller's Tale); see also Hazelwood Hits Home at Darien High School, 14 Conn. Law Trib. 4 (May 16, 1988); "Ripple Effect" of High Court's Press Ruling Seen as Test of Schools' Journalism Policies, Educ. Week, Feb. 10, 1988, at 1, col. 2.

75. The Court held that the paper was "developed within the adopted curriculum," $108 \mathrm{~S}$. Ct. at 568-69 (quoting Hazelwood Curriculum Guide), and was part of "regular classroom activities." Id.; see also id. at 570 . Decisions about curricula should be reviewed under the relevant precedents; Meyer, Pierce, Barnette, Tinker, and Pico. See id. at 574 (Brennan, J., dissenting); see also Note, High School Newspapers and the Public Forum Doctrine: Hazelwood School Dist. v. Kuhlmeier, 74 VA. L. Rev. 843, 859-61 (1988) (Supreme Court should have applied Tinker v. Des Moines School District, 393 U.S. 503 (1969)). Kuhlmeier did not discuss the orthodoxy analysis in Meyer, Pierce, Barnette, or Pico. It distinguished student speech like that in Tinker from "student speech in schoolsponsored expressive activities," $108 \mathrm{~S}$. Ct. at 570-71, such as "a school-sponsored publication, theat- 
sponsored student expression" from whole cloth. ${ }^{76}$ Finally, this broad new category obscures the opinion's relatively minor modification of Tinker. Tinker protected students from disturbances in public schools; Kuhlmeier extends that same protection to parents. ${ }^{77}$ Its influence can best be diminished if courts have an alternative. To do this, the opportunity apparent in the Pico plurality opinion must be seized.

\section{A New Definition of Orthodoxy}

This Section defines orthodoxy in terms of how ideas are taught. It draws on studies of secondary school textbooks in American history and studies of how ideas are transmitted. These studies emphasize that students need not fear conformity. ${ }^{78}$ They demonstrate that schools reinforce

rical production, or other vehicle of student expression." Id. at 571. See infra note 76 (criticizing new category).

76. Tinker did not distinguish between state-sponsored speech and student speech that fortuitously occurred on school grounds. Tinker, 393 U.S. 503 (1969). See 108 S. Ct. at 575 (Brennan, J., dissenting). Bethel School District $v$. Fraser concerned a student speech nominating a fellow student for state-sponsored student government and given at a school-sponsored assembly. 478 U.S. 675 (1986). Yet Fraser applied Tinker's standard in upholding punishment of the student for making a disruptive speech; see also Kuhlmeier, 108 S. Ct. at 575 (Brennan, J., dissenting).

Kuhlmeier also ignored the doctrinal significance of incorporating First Amendment rights. Meyer and Pierce evaluated school policies under the reasonable relation test of the Fourteenth Amendment. See Meyer v. Nebraska, 262 U.S. 390, 403 (1923). Barmette held that the First Amendment required a more stringent test. See West Va. State Bd. of Educ. v. Barnette, 319 U.S. 624, 639 (1943). Kuhlmeier reinstated the reasonableness test. $108 \mathrm{~S}$. Ct. at 571.

The new category of "school-sponsored student speech" may limit Kuhlmeier's reach. See Burch v. Barker, 861 F.2d 1149 (9th Cir. 1988) (refusing to apply Kuhlmeier to underground newspaper). Student speech that is not school-sponsored should still be subject to Tinker's standard. Id. See Abrams \& Goodman, End of an Era? The Decline of Student Press Rights in the Wake of Hazelwood School District v. Kuhlmeier, 1988 Duke L.J. 706 (Kuhlmeier will not reach independent student publications).

77. Tinker expressly allowed school officials to limit student speech that might "impinge upon the rights of other students." See Tinker, 393 U.S. at 509. The principal argued that the excised articles would violate the rights of other students and their parents. Kuhlmeier therefore merely extended Tinker to include parents, as well as students. Decisions about curricula might not implicate others' rights as did newspaper articles about divorce and teenage pregnancy. (In cases under the free exercise clause, plaintiffs have alleged that mere exposure to ideas infringed their free exercise of religion. See, e.g., Grove v. Mead School Dist. No. 354, 753 F.2d 1523 (9th Cir. 1985). These cases are outside the scope of this Note.)

78. A recent review of empirical research into what students know concluded:

[S]chools are social sites characterized by overt and hidden curricula, tracking, dominant and subordinate cultures, and competing class ideologies. Of course, conflict and resistance take place within asymmetrical relations of power which always favor the dominant classes, but the essential point is that there are complex and creative fields of resistance through which classrace- and gender-mediated practices often refuse, reject, and dismiss the central messages of the schools.

Giroux, Theories of Reproduction and Resistance in the New Sociology of Education: A Critical Analysis, 53 Harv. Educ. Rev. 257, 260 (1983); see also Gritical Pedagogy \& Cultural Power (D. Livingstone ed. 1987). The diversity of viewpoints in public schools may well grow, as more and more groups petition school authorities to include their viewpoints or experiences in educational materials. See supra note 68 . Of course, not all students have access to information that counters every idea articulated by school officials. Nevertheless, diversity of information allows students to select what they think is important from a range of alternatives and provides students with materials with which they can reject value judgments advocated by school officials. See infra note 79 (describing "resistance" theory).

Sociologists have concentrated on this diversity of viewpoints in public schools only recently. Re- 
ideas favored by school officials even while giving students access to disfavored ideas. ${ }^{79}$ The Note proposes a definition of orthodoxy that takes that

searchers had assumed there was one ideology taught in public schools and had devoted themselves to excavating the one ideology taught by schools. See, e.g., S. Bowles \& H. GinTIS, Schooling IN CAPITAlist America (1976) (public schools assimilate working class to capitalism); Arons \& Lawrence, The Manipulation of Consciousness: A First Amendment Critique of Schooling, 15 HaRv. C.R.-C.L. L. REv. 309 (1980) (assuming that societies coalesce around one dominant ideology). In the mid-1970's, however, sociologists began to focus on the diversity of views and cultures expressed by students and teachers, rather than to look for a single underlying ideology in schools. Two classic studies were P. Bourdieu \& J.-C. PASSERON, REPRoduction In Education, SOCIETY and CuLTURE 197-210 (1977) (French education system), and P. Willis, LEARNING TO Labour: How Working Class Kids Get Working Class Jobs (1977) (English elementary schools). The consequences of the shift in method are described in Giroux, supra, at 258-59, 282-83 (critiquing expanded scope of recent educational research); Apple \& Weis, Introduction, in IDEOLOGY AND PRACTICE IN Schooling 12-16 (M. Apple \& L. Weis eds. 1983) (same).

79. This conclusion arose from the theory of "resistance." Researchers found that people who did not benefit from distributions of power and resources often had beliefs and values directly opposing those of more powerful groups; often, the same words and gestures took on diametrically opposed meanings in different social classes. See, e.g., L. LABov, Sociolingistic PATterns (1972). Further research along these lines uncovered an overwhelming diversity of viewpoints within each society, and, more importantly, a strong tendency among members of the lower classes to reject any claim to privilege made on behalf of powerful classes. In short, resistance theory researchers found that there was no single ideology controlling most citizens' reaction to the structure of their society. See N. ABERCrombie, S. Hill \& B. Turner, The Dominant Ideology Thesis (1980).

Researchers next asked, if there were many diverse and opposing beliefs in a society, what kept the society together? They proposed three answers. The first explanation simply noted that oppositional groups are powerless to unseat dominant groups. This impotence worsened when members of the oppositional groups, recognizing their inability to reshape society, refused to participate in activities that might promote change beneficial to them. See, e.g., P. Willis, supra note 78 (examining process by which working class students adopt nonoppositional stances).

Other scholars advanced explanations that concentrated on discourse. They argued that members of oppositional groups could not articulate programs for social change because they (and their intended audience) used "restricted codes," in contrast to the "elaborated codes" of the upper classes. See 1 B. Bernstein, Ci.ASS, CODES, AND Control (1971). This answer overlooked the sophistication of "lower class" codes. See, e.g., L. LABOv, supra (arguing that "Black English" fulfilled all purposes of "White English"); Fowler, Power, in 4 HANDBook of Discourse ANALYsis: Discourse AÑLysis IN SOCIETY (T. van Dijk ed. 1985) [hereinafter HANDBOOK] (surveying developments since Bernstein's studies).

Out of the rudimentary distinction between "restricted" and "elaborate" codes grew a third, more sophisticated approach. Pierre Bourdieu, for example, argued that communities were built on structures of beliefs and meanings. As in any structure, some beams could be altered or even removed without endangering or changing the structure, while others could not be touched at all. Disagreement with the latter "beams" was difficult if not impossible within the community's language; the "restricted code" was intrinsic to membership in the community, and was not limited to the lower classes, as Bernstein suggested.

But matters were even more complex than this. There were structures within the areas of disagreement, Bourdicu contended. An idea's position within that structure predisposed a member of the community to favor or disfavor it. These predispositions were akin to presumptions and, as such, could be overcome by almost all members of the community in some circumstances and by some individual members at any time. Such variations notwithstanding, a researcher could identify the norms of a group by excavating the structure which shaped its beliefs. See P. Bourdieu, Distinction: A Social Critique of the Judgment of TAste (R. Nice trans. 1984) (examining aesthetic and consumer preferences).

John Thompson surveyed Bourdieu's work and similar efforts. He concluded that societies did not coalesce around a set of beliefs that was internally consistent but instead around the ability to use a vocabulary in ways that mask disagreements. J. THOMPSON, STUdies IN THE THEORY OF IDEOLOGY 5 (1984). The danger, as Fowler and Thompson noted, was that some interpretations within that vocabulary were "associated with situations of prestige, success, and authority, and some with situations of powerlessness and deprivation." See Fowler, supra, at 62. 
reality into account. ${ }^{\mathbf{8 0}}$

Jean Anyon studied high school textbooks on United States history, especially their coverage of populist programs for political and economic reform. ${ }^{81}$ Anyon found that radical unions, their leaders, and their policies were ignored, insulted, or dismissed as dishonest; ${ }^{\mathbf{8 2}}$ that the possibility of government regulation being co-opted by business was never mentioned; ${ }^{83}$ that the books discussed only strikes that ended in violence and ultimately

It is important to emphasize that these scholars did not paint a conspiratorial picture of public discourse. In their view, it was not necessary to believe that elites controlled public discourse. They argued that flaws in public discourse emanated from the structure of the community itself. See, e.g., P. BouRdieu, supra. Hence, it was not surprising that the barriers to full discussion of alternative ideas appeared in the writings of those who favored change. See, e.g., Fowler, supra, at 76; see also infra note 90 (discussing studies by Fowler and others).

80. The researchers relied on here examined how the surface features of public discourse reflected ideas' role in maintaining power relationships between men and women, between races, and between social and economic classes. This tradition can be labelled "political discourse analysis." The original discourse analysts focused on micro-interactions, such as those between two people, among smal! groups, or in the classroom. They examined how social structure was embedded in the minutiae of daily life, for example, in how men or women took turns while conversing, or in men's dominance of conversational topics. They also studied the ways that meanings were negotiated within groups, and revealed mechanisms by which some meanings rose to prominence while others were marginalized.

During the 1970's, European social theorists expanded the scale of discourse analysis to see, for example, who speaks in society, what turn-taking was allowed, how shared symbols had different meanings in different social groups, and how these differences reflected power imbalances. They argued that language was "constitutive" of social reality. In saying language constructed sacial reality, they did not advance the naive claim that language conferred power on people or institutions that would otherwise have lacked it. Rather, they argued that language created a set of relationships among people, and between people and the institutions of their saciety, in which existing distributions of power seemed natural. The important corollary of this thesis was that it became difficult (literally "unnatural") to articulate ideas or grievances that challenged these distributions. See M. HALliDAY, Language As Social Semiotic (1978). Political discourse analysts contended that silences in public discourse protected institutions that benefited those with power. See, e.g., R. FowLER, R. HODGE, G. Kress \& T. Trew, Language and Control. 35-36 (1979); see also F. Burton \& P. Carlen, Official Discourse (1979); P. Goodrich, Legal Discourse 125-39 (1987).

The political discourse analysts' perspective on the role language played in maintaining power did not originate the politically sensitive analysis of public discourse. Relevant, exemplary studies include T. ARnold, The Folklore of Capitalism (1936); K. Burke, A Rhetoric of Motives (1950); and Veblen, The Captains of Industry, in THE PORTABLE VEBLEN (1976) (analyzing the rhetoric of entrepreneurship). In the overtness of their political turn, however, the political discourse analysts were unique. Teel van Dijk, for example, hoped that studies establishing that mass media reinforced existing power distributions would change journalistic practice. See van Dijk, Introduction, in HaNDвоOK, supra note 79 , at 8 . Fowler called upon sociolinguists to infuse a "social purpose" into their investigations. See Fowler, supra note 79, at 62.

The basic insight should not be new to legal scholars. Joseph Vining argued that standing doctrines operated by making it difficulty to describe certain conditions as deserving of legal remedy. See J. VINING, LEGAL IDENTITY (1978). The thesis that language created and reinforced relationships that were self-perpetuating was central to the law and rhetoric movement. See J. WHITE, WHEN WordS LOSE Their MEANINGs (1984). The political turn of the discourse analysts' work had the transformative aspirations typical of work in the Critical Legal Studies movement.

81. Anyon, Workers, Labor and Economic History, and Textbook Content, in Ideolocy AND PrACTICE IN SCHOOLING, supra note 78, at 37. Anyon examined 17 textbooks approved for use in two large Northeastern cities. See also Anyon, Ideology and U.S. History Textbooks, 49 Harv. Educ. REv. 361 (1979). Anyon's results have been replicated in Gottlieb, In the Name of Patriotism, supra note 66 (conducting independent review of high school American history texts, as well as reviewing other studies).

82. Anyon, Workers, Labor and Economic History, and Textbook Content, supra note 81, at 42-46.

83. Id. at $41-42$. 
did not get workers what they wanted; ${ }^{84}$ and that reformist leaders and moderate reform legislation were lauded..$^{85}$ Anyon noted that each position taken in the texts was controversial among professional historians. The books' favorable treatment of reform legislation, Anyon argued, could be explained only by an ideological bias: the books were meant to reinforce contemporary institutions by linking them to policies and people highly praised in the books. Anyon contended that the books substantially affected students' political beliefs. ${ }^{86}$

Anyon did not attend to the linguistic techniques by which the texts conveyed their approval of reform measures. His evidence revealed that two techniques consistently reappear. First, concepts essential to both reformist and populist proposals were described in terms appropriate only to the reform proposals. For example, many texts explained economics as fueled by competition between self-interested individuals. Because some populists argued that productivity arose from cooperation among individuals, their suggestions to reorient the economic system-elimination of forprofit enterprises, for example-struck school children as ridiculous. ${ }^{87}$ Another concept on which populists often disagreed with reformists was the thesis that the working class was united against those who owned the means of production. The texts emphasized that race and culture divided workers against each other ${ }^{88}$ Anyon contended that the texts ignored employers' efforts to create and exploit divisions among workers. The texts thus discussed the working class solely in terms of the divisions between workers acknowledged and fostered by capitalism. ${ }^{89}$ Consequently, stu-

84. Id. at 43-44.

85. Id. at $39-40,49-51$.

86. Id. at 49-53 \& nn.1, 70-74; see also Freebody \& Baker, Children's First Schoolbooks: Introduction to the Culture of Literacy, 55 HARv. Educ. Rev. 381 (1985) (original study arguing that reading primers reinforce gender and class stereotypes; review of literature on effects of textbooks on childrens' worldviews). But see van Geel, supra note 2, at 262-87 (arguing that schools are ineffective in inculcating values). Van Geel assumed that value inculcation attempted to achieve conformity. Its failure to do so made his conclusion easy to reach. Political discourse analysts argued that orthodoxy allows diversity. See supra notes 78-80.

87. Anyon, Workers, Labor and Economic History, and Textbook Content, supra note 81, at 49-50.

88. Id. at $45-47,51$.

89. Id.; see also D. MONTGOMERY, WORKERS' CONTROL IN AMERICA 153-54 (1979) (criticizing history courses on same ground).

The constriction of possibilities appeared in other contexts as well. Raymond Williams noted that "democracy" once called for self-expression and broad participation in a variety of community organizations. In contemporary America, "democracy" referred only to voting and paying taxes. See R. WiLliams, KeYwoRds 93-98 (rev, ed. 1983). The Supreme Court sharply limited avenues for popular participation in political decisions. See, e.g., Minnesota St. Bd. for Community Colleges v. Knight, 465 U.S. 271, 285 (1984) ("Disagreement with public policy and disapproval of officials' responsiveness . . . is to be registered principally at the polls."). An attempt to recapture the original meaning of "democracy" is Note, Petitioning and the Empowerment Theory of Practice, 96 YALE L.J. 569 (1987) (First Amendment right of petition should be interpreted expansively to increase power of marginal groups in society).

The short spectrum of political possibilities appeared also in mass media reports of popular political actions. In a study of nightly news broadcasts, Jensen found that labor protests were evaluated in terms of their effect on upcoming elections. This interpretation precluded the possibility that these 
dents developed constricted senses of what alternatives fit American history. ${ }^{90}$

Second, the texts depicted radical economic programs as utopian speculation. Although they discussed populist proposals, they omitted populists' specific proposals to reform the economic system. In contrast, discussions of reformist proposals specified how those programs were implemented, including details of legislation and the personalities of the presidents, labor leaders, captains of industry, and legislators who carried them out. Radical alternatives appeared to be airy things, incapable of providing concrete guidance for daily life. ${ }^{91}$

In other contexts, the linguistic devices used to undercut alternatives' persuasiveness might be unproblematic. In public schools, however, these texts transmit a community judgment without allowing students to examine that judgment. This practice dictates what the students should accept as commonsensical and practical. In doing so, it vitiates the schools' ability to develop the skills for self-government. The prose of the texts seem to "deny all possibility of reflection on change in the future. . . . In its flatness and its uncritical conformism, [the prose of American history textbooks] is a kind of American socialist realism."'92

protests might represent direct action outside the electoral process. It thereby restricted the definitions of both union activity and politics. See Jensen, News As Ideology: Economic Statistics and Political Ritual in Television Network News, 37 J. Communication 8 (1987).

90. See supra note 86 (analyzing effects of textbooks). Studies of public discourse confirmed the effectiveness of the strategy of defining key terms with reference only to one policy alternative. Fowler studied newspaper articles criticizing delays in surgical treatment in the United Kingdom. Although advocating proposals to give people more control over their treatment, these articles linked nouns referring to patients to mental states or to things patients do to themselves. Nouns referring to doctors and policymakers were active, often taking nouns referring to patients as objects. Fowler, Power, in HANDBOoK, supra note 79, at 79-80. Fowler concluded that the reports' "language unwittingly reproduces the attitudes that block reform. This conventional middle-class discourse, quite ordinary in its stylistic character, is impregnated with discriminatory assumptions." Id. at 81 . The language provided no suggestion for how patients can be made more active. They thus made even minimal reforms seem impractical. This pattern repeated itself, to the same end, in language that described women as inanimate objects, men as agents, see Seidel, Political Discourse Analysis, in id. at 53-55; in public discourse about the homeless, see Sykes, Discrimination in Discourse, in id. at 89; and in discussion of social conflicts, see R. Fowler, R. HODGE, G. KREss \& T. TREw, supra note 80, at 117-56. See generally Discourse and Discrimination (G. Smitherman-Donaldson \& T. van Dijk eds. 1988).

91. Anyon, Workers, Labor and Economic History, and Textbook Content, supra note 81, at 51 .

Michel Pecheux supported this conclusion. He distributed identical sections of a single political platform to two groups with similar backgrounds. One group, told the passages were extracted from the platform of a left-wing political party, described the platform as containing unformed intentions to achieve vaguely-phrased goals; members of the other group, told that the identical passages came from the platform of a right-wing group, paraphrased it as including relatively detailed commands to be implemented by existing institutions. The only variable was the respondents' information about the political orientation of the authors. The discrepancy in interpretations suggested that the norms for interpreting left-wing thought were substantially different from those used in deciphering right-wing proposals. The effect of this difference was to make the left-wing thought appear impractical. Pecheux, Are the Masses an Inanimate Object?, in Linguistic Variation: Models and MethoDs 251 (D. Sankoff ed. 1976); see also Gottlieb, supra note 66, at 505 n.36 (texts' description of public protests as not influencing U.S. policy in Vieinam made protest and participation seem ineffectual).

92. F. Fitzgerald, America Revised 162 (1979); accord Gordon, supra note 71, at 566 (advocacy of capitalism in public schools imposes orthodoxy on students). 


\section{Implementing The Discourse Analytic Approach}

The discourse analytic research points the way toward a new way of resolving the conflict between schools' inculcative function and the need to equip students for self-government. Schools fail to prepare students to criticize when they describe ideas disfavored by school officials using the two techiniques outlined above, restricted definition and utopianism. These tactics tilt the playing field against disfavored ideas and immunize favored ideas from criticism. Schools therefore must not employ them.

Concentrating on these two techniques-restricted definition and utopianism-accomplishes two things that other approaches do not. First, it dissolves the dilemma posed by the twin demands of inculcation and preparation for self-government. The approach suggested here allows schools to advocate community values vigorously. It simply forbids them from doing so unfairly. It therefore eliminates the need for value neutrality. This reduces the likelihood that courts will feel compelled to cut back on students' First Amendment protections in order to allow schools to argue for community values. It thus provides both greater latitude for schools and greater security for students' First Amendment protections. ${ }^{\text {9s }}$

Second, the approach advocated here responds to the reality of students' access to information. Ideas reach students in today's society. The problem is to insure that students know how to take those ideas seriously. Simply giving them more information will not help accomplish this.

The approach properly develops the orthodoxy doctrine. The discourse analytic research on which it relies uncovers a new prerequisite for selfgovernment. In keeping with the development of the orthodoxy doctrine, the approach advocated here incorporates the prerequisite into that doctrine. It also picks up on the hint in Tinker that schools may not unduly influence the evaluation of ideas once ideas are admitted to the school. It thus fulfills the promise of Pico.

Courts can begin the process of implementing this approach. They should announce that how ideas are taught will be reviewed under the prescriptions against orthodoxy. This declaration will shift attention from the content of curricula to the way ideas are discussed. The burden of implementing this falls on communities. Challenges to decisions of school authorities will force public discussion of school boards' progress in eliminating orthodoxy. Vibrant public discourse about education will by its very existence help implement American society's commitment to "unin-

93. It is of course true that teachers occupy a place of power that enhances the persuasiveness of the ideas they endorse. The aim of training students for citizenship, however, does not require that students disagree at the time they hear ideas. Instead, it hopes to insure that students will learn the techniques by which ideas may be criticized. Hence, even if they never disagree with any given idea advocated by a faculty member, they will come away from the school with the ability to criticize ideas, and some of the resources for doing so. See supra notes 78 \& 79 (describing students' access to ideas and resistance theory). 
hibited, robust, and wide-open"94 public debate, as groups with substantive disagreements and clashing interests argue about how school authorities can best eradicate orthodoxy. ${ }^{95}$

Educational scholars have proposed many ways the requirement can be implemented. For example, "democracy" should be described as a way that people can participate in the activities of their own government; any particular institution, whether circle of workers or republican legislature, would be evaluated in terms of its efficacy at promoting popular initiatives; if necessary, alternative routes to participation such as protest ${ }^{96}$ and petitioning the legislature ${ }^{97}$ may be discussed. ${ }^{98}$ In history texts one might include information about alternative ideas advanced in a particular historical period. ${ }^{98}$ Alternatively, schools might provide exercises for students to discuss how utopian ideas might be made practical. ${ }^{100}$

94. New York Times v. Sullivan, 376 U.S. 254, 270 (1964).

95. This proposal would not compel schools to teach beliefs widely-regarded as evil. First, those beliefs would not pass the test announced here. Many, if not most, "evil" beliefs rely on one or both techniques for impairing criticism. Racist beliefs, for example, define "humanity" restrictively by reference to the characteristics and beliefs of one culture.

It is possible that an "evil" belief might not violate the requirement against using the two techniques outlined in the text. In that case, this proposal might be the best antidote to such beliefs. It would expose them to criticism that they would not otherwise receive and would insure that students hear that criticism. The political discourse analysts devote much of their work to excavating and defusing racist, sexist, or other "evil" beliefs in public discussion. See the works discussed in notes 78-80.

Finally, the problem of evil beliefs is irrelevant to this proposal. Within the parameters laid down by current law, communities can decide for themselves what beliefs will be discussed in public schools. This proposal regulates only how the chosen topics will be discussed. The proposal does not require that every idea be taught in public schools.

96. Gotllieb, supra note 66 , at 572-73.

97. See Note, supra note 89.

98. Paolo Freire directed literacy projects in a number of countries newly freed from colonial rule. $\mathrm{He}$ found that his students believed that colonial structures and values were immutable. He encouraged them to work through practical, daily problems. They saw that those institutions and values had grown in response to particular historical challenges. They also saw how they could re-design those institutions as they faced new challenges. See Freire, The Problem-Posing Concept of Education as an Instrument for Liberation, in EduCATION IN AMERICAN CULTURE 392-93 (E. Steiner, R. Arnove \& B. McClellan eds. 1980); see also O'Neil, Decolonization and the Ideal Speech Community: Some Issues in the Theory and Practice of Communicative Competence, in CRITICAL THEORY AND Public Life 57, 69-71 (J. Forrester ed. 1985) (step by step introduction to Freire's pedagogy); Misgeld, Education and Cultural Invasion: Critical Social Theory, Education as Instruction, and the "Pedagogy of the Oppressed," in id. at 77, 105 (explaining relevance of Freire's work to educational planning).

99. Anyon, Workers, Labor \& Economic History, and Textbook Content, supra note 81, suggested that texts include information about the people advocating radical ideas and the specific proposals they made. Gottlieb, In the Name of Patriotism, supra note 66, argued that texts must note that political protests sometimes succeed.

100. Freire again provides a model. His "pedagogy of the oppressed" encouraged students to talk about utopian or unbelievable ideas in terms of the practical effects those ideas, if implemented, would have on their own lives. While tracing the impact these "utopian" ideas might have on them, students speculated about how the ideas could be adopted. Consequently, they began to see these ideas as practical rather than utopian. See Freire, supra note 98; see also Bundy, Social Visions and Educational Futures, in Society, Culture, and Schools: The AMERICAN Approach 363, 377-80 (1979); Gitlin, School Structure and Teacher's Work, in IDEology and Practice IN SCHOOLING, supra note 78, at 193, 210-11 (1983); Apple, Curricular Form and the Logic Technical Control, in id. at 143, 159-60 (suggested science curricula). 


\section{Conclusion}

Broadening the interpretation of the ban on orthodoxy will nurture the "individual freedom of mind" necessary for self-government. The development of a critical public attitude can only be enhanced by the fact that it will begin with the education of students for "active and effective participation in [a] pluralistic, often contentious society,"101 a society they will learn to keep free of any orthodoxy.

101. Pico, 457 U.S. at 868 (opinion of Brennan, J.). 
